\title{
Assessment of the correlation between oxidative stress and expression of MMP-2, TIMP-1 and COX-2 in human aortic smooth muscle cells
}

\author{
Katarzyna Oszajca, Janusz Szemraj
}

Department of Medical Biochemistry, Medical University of Lodz, Lodz, Poland

Submitted: 20 March 2021

Accepted: 21 July 2021

Arch Med Sci Atheroscler Dis 2021; 6: e158-e165

DOI: https://doi.org/10.5114/amsad.2021.109255

Copyright @ 2021 Termedia \& Banach

\section{Abstract}

Introduction: Smooth muscle cells (SMCS) are considered to be the main producer of matrix metalloproteinase-2 (MMP-2) participating primarily in extracellular matrix (ECM) remodeling. Any disturbances in ECM structure may underlie the pathogenesis of many cardiovascular diseases and contribute to angiogenesis, cancer development, invasion or metastasis. The purpose of the study was to examine the effect of oxidative stress on the expression of MMP-2, its tissue inhibitor type 1 (TIMP-1) and cyclooxygenase-2 (COX-2) in human aortic smooth muscle cells (HASMCs).

Material and methods: HASMCs were treated with exogenously applied $\mathrm{H}_{2} \mathrm{O}_{2}$ or TNF- $\alpha$. N-acetylcysteine (NAC) was used as an antioxidant. Gene expression levels were measured by real-time PCR and the protein levels were determined using ELISA assay.

Results: The studies revealed no association between oxidative stress and either mRNA quantity or protein secretion of MMP-2 and TIMP-1. However, we found markedly reduced $(p<0.001)$ MMP-2 secretion in cells incubated with NAC. HASMCs stimulated with TNF- $\alpha$ demonstrated a significantly increased COX-2 mRNA level as well as enzyme activity. $\mathrm{H}_{2} \mathrm{O}_{2}$-induced cells showed lowered COX-2 activity in comparison to untreated cells. MMP-2 and TIMP-1 expression did not change after COX-2 inhibition with DuP-697. Conclusions: We did not find any effect of oxidative stress on expression of MMP-2 and TIMP-1 in HASMCs. However, COX-2 mRNA and protein level were elevated in these conditions. There was no correlation between COX-2 activity and MMP-2 and TIMP-1 mRNA expression or protein secretion.

Key words: hydrogen peroxide, oxidative stress, tumor necrosis factor- $\alpha$.

\section{Introduction}

Metalloproteinases (MMPs) belong to a group of zinc-dependent endopeptidases produced and secreted by multiple cell types, including inflammatory cells and vascular smooth muscle cells (SMCs), both in physiological and pathological states. They possess the capacity for proteolytic degradation of extracellular matrix (ECM) proteins such as collagens, proteoglycans, elastin and fibronectin. SMCs constitute a major cellular component of the arterial wall and play a crucial role in regulating vascular tone and producing the ECM framework of the vessel wall. Vascular SMCs are generally surrounded by and embedded in a variety of ECM proteins. Any modifications in ECM structure, in particular resulting from

\author{
Corresponding author: \\ Katarzyna Oszajca \\ Department of \\ Medical Biochemistry \\ Medical University \\ of Lodz \\ 6/8 Mazowiecka St \\ 92-215 Lodz, Poland \\ Phone: +48 422725687 \\ E-mail: katarzyna.oszajca@ \\ umed.lodz.pl
}


MMP activity, lead to vascular remodeling. Therefore, MMPs can participate in pathogenesis of many cardiovascular diseases, such as atherosclerosis or aneurysms. They also play a major role in angiogenesis, cancer development, invasion and metastasis. Expression and activity of MMPs are regulated at the transcriptional level by various cytokines, at the protein level by proenzyme activation, and at the active enzyme level by exogenous and endogenous inhibitors [1, 2]. The understanding of the factors influencing the expression and activity of MMPs and their tissue inhibitors seems to be very important to clarify the pathomechanism of many disorders. One such factor could be reactive oxygen species (ROS), involved in numerous processes occurring inside the cells both physiologic and pathologic.

The goal of the study was to elucidate the correlation between externally applied hydrogen peroxide $\left(\mathrm{H}_{2} \mathrm{O}_{2}\right)$, which is a cell-permeable oxidant, or endogenously generated $\mathrm{H}_{2} \mathrm{O}_{2}$ after tumor necrosis factor $\alpha$ (TNF- $\alpha$ ) stimulation, and the expression of MMP-2 and TIMP-1 in human aortic smooth muscle cells. MMP-2 belongs to the gelatinases that degrade type IV collagen in basal membranes, as well as collagen V, VII, X, elastin and gelatin. The changed activity of this proteolytic enzyme or its tissue inhibitor, TIMP-1 under pathological conditions may contribute to the development of many cardiovascular diseases [3-6] or cancers [7-10].

Additionally, in this research we investigated the effect of $\mathrm{H}_{2} \mathrm{O}_{2}$ and TNF- $\alpha$ on cyclooxygenase-2 (COX-2) expression level and activity, as well as the possible relationship between COX-2 activity and MMP-2 and TIMP-1 expression. COX-2 is an inducible enzyme converting arachidonic acid to prostaglandins (PGs) at the site of inflammation and is linked to several physiological and pathological pathways related to angiogenesis, inflammation or invasiveness [11, 12].

\section{Material and methods}

\section{Cell culture and treatment}

The cryopreserved human aortic smooth muscle cells (HASMCs) pooled from a single donor were purchased as cryopreserved samples from Gibco (Life Technologies). The cells were grown in Medium 231 (Gibco) supplemented with 5\% smooth muscle growth supplement (SMGS, Gibco) and 1\% gentamicin/amphotericin B solution (Gibco) at $37^{\circ} \mathrm{C}$ in a $95 \%$ humidified atmosphere of $5 \% \mathrm{CO}_{2}$. The medium was replaced every 2-3 days. At confluence, cells were subcultured by trypsinization (using $0.025 \%$ trypsin $-0.01 \%$ EDTA solution, Gibco), after which the cells were seeded with a split ratio of $1: 3$. Cell viability was evaluated using MTT (3-(4,5-dimethylthiazol-2-yl)-2,5-diphenyltetrazoli- um bromide) assay (Sigma Aldrich) performed in 96-well plates. Measurements were taken by the multiwell plate reader (Multiskan Ascent) with an appropriate filter set $(570 \mathrm{~nm})$. Cultures at 4-7 passages were used in the experiments. Before all experiments the cells were synchronized by $24 \mathrm{~h}$ starvation in SMGS- and antibiotic-free Medium 231. Then the cells were preincubated for $30 \mathrm{~min}$ with or without $1 \mathrm{~mol} / \mathrm{l} \mathrm{N}$-acetylcysteine (Sigma-Aldrich) and/or 10 nmol/I DuP-697 (Cayman Biochemicals) followed by treatment with hydrogen peroxide (50 and $150 \mu \mathrm{mol} / \mathrm{l})$ or TNF- $\alpha(50 \mathrm{ng} / \mathrm{ml})$ for $24 \mathrm{~h}$. Untreated cells constituted a control.

\section{Real-time PCR}

Cell lysis, cDNA synthesis and real-time PCR were performed using the Power SYBR Green Cells-to-Ct Kit (Ambion/Thermo Fisher Scientific) according to the manufacturer's protocol. Briefly, treated and untreated smooth muscle cells were directly lysed for $5 \mathrm{~min}$ at room temperature with Lysis Solution (provided in the kit) in 96-well culture plates after washing with phosphate-buffered saline (PBS). Cell lysates were reverse transcribed to synthesize cDNA using the RT Enzyme Mix and SYBR RT Buffer. Then CDNA was amplified by real-time PCR on the Stratagene Mx3005P System (Agilent Technologies) using Power SYBR Green PCR Master Mix and the specific primers as follows: MMP-2 forward primer 5' ATGAATACTGGATCTACTCAGC 3' and reverse primer 5' GTATCTCCAGAATTTGTCTCC 3', TIMP-1 forward primer 5' CACCTTATACCAGCGTTATG $3^{\prime}$ and reverse primer 5' TTTCCAGCAATGAGAAACTC 3', COX-2 forward primer $5^{\prime}$ TGGAATTACCCAGTTTGTTG $3^{\prime}$ and reverse primer 5' TGCGGTACTCATTAAAAGAC 3', GAPDH forward primer 5' CTTTTGCGTCGCCAG 3' and reverse primer $5^{\prime}$ TTGATGGCAACAATATCCAC 3' (Sigma-Aldrich). The amount of target mRNA was normalized to GAPDH, and the relative gene expression was calculated by the formula $2^{-\Delta \Delta C t}$ using samples from the control group as calibrator samples $[13,14]$.

\section{Enzyme-linked immunosorbent assay (ELISA)}

For the measurement of MMP-2 and TIMP-1 protein levels in cell culture supernatants, Human MMP-2 ELISA and Human TIMP-1 ELISA kits (Sigma-Aldrich) were used. The quantity of prostaglandin E2 (PGE2), the product of COX-2 activity being released into the cell culture medium, was determined by the ELISA Kit from Abnova. Before the experiments, the HASMCs were grown in 6-well plates and were treated with experimental reagents as described above. Additionally, in the case of PGE2 level determination, one hour before the end of the incubation period, arachidonic acid 
(substrate for COX-2) was added to the cell culture medium at the final concentration of $15 \mu \mathrm{mol} / \mathrm{l}$. Cell culture supernatants were collected, centrifuged and frozen at $-80^{\circ} \mathrm{C}$ until analysis. The assays were carried out following the instructions provided by the manufacturers. The absorbances were measured at $450 \mathrm{~nm}$ (for MMP-2 and TIMP1 assays) or at $405 \mathrm{~nm}$ (for PGE2) on the Glomax Multi Detection System (Promega). The obtained concentration values were normalized to the total protein content as measured by the Micro BCA Protein Assay Kit (Thermo Fisher Scientific) from each cell lysate.

\section{Statistical analysis}

Statistical analysis was performed using Statistica StatSoft Version 12. Data are expressed as the mean \pm standard deviation. The results were analyzed by one-way ANOVA. When differences were indicated, Tukey's post-hoc test for multiple comparison was used to determine the significance. $P$-value $<0.05$ was considered statistically significant.

\section{Results}

The effect of $\mathrm{H}_{2} \mathrm{O}_{2}$ and TNF- $\alpha$ on the mRNA expression level of MMP-2 and TIMP-1 in HASMCS

The oxidative stress originating from exogenously added $\mathrm{H}_{2} \mathrm{O}_{2}$ or endogenously generated after TNF- $\alpha$ stimulation did not significantly influence the MMP-2 and TIMP-1 mRNA amounts in HASMCs in comparison to untreated cells (Figure 1). The preincubation of cells with an antioxidant NAC also did not show any significant differences in mRNA levels of both genes between control and experimental groups of cells. In the case of the TIMP-1 gene the relative mRNA quantity was

A

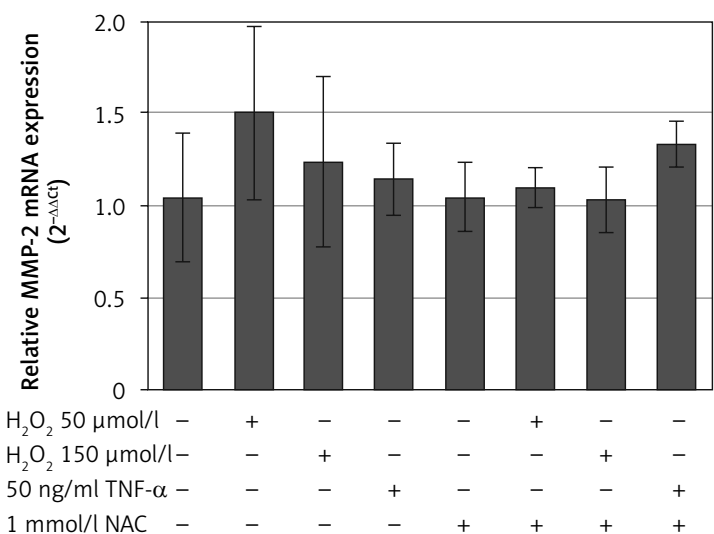

elevated by more than $30 \%$ in cells treated with $\mathrm{NAC}$ both alone and treated simultaneously with $50 \mu \mathrm{mol} / / \mathrm{H}_{2} \mathrm{O}_{2}$, but the difference did not reach statistical significance. Additionally, the increase of TIMP-1 mRNA level in cells incubated with NAC and $150 \mu \mathrm{mol} / / \mathrm{H}_{2} \mathrm{O}_{2}$ was borderline significant ( $p=0.0499)$ compared with control cells.

\section{The effect of $\mathrm{H}_{2} \mathrm{O}_{2}$ and TNF- $\alpha$ on secretion of MMP-2 and TIMP-1 from HASMCs}

The ELISA results showed no significant effect of $\mathrm{H}_{2} \mathrm{O}_{2}$ and TNF- $\alpha$ on MMP-2 and TIMP-1 release from smooth muscle cells to the culture medium (Figure 2). However, we found markedly $(p<0.001)$ reduced MMP-2 secretion in cells incubated with $\mathrm{NAC}$, both in the absence and the presence of $\mathrm{H}_{2} \mathrm{O}_{2}$ compared to the control cells. A slight decrease (by about $30 \%$ ) in MMP-2 release upon NAC administration was also observed in TNF- $\alpha$-stimulated cells but the difference did not reach the level of statistical significance $(p>0.05)$.

\section{The effect of $\mathrm{H}_{2} \mathrm{O}_{2}$ and TNF- $\alpha$ on COX-2 mRNA expression and protein activity}

HASMCS stimulated with TNF- $\alpha$ expressed about a twofold larger amount of COX-2 mRNA than unstimulated cells $(p=0.011)$. An increase of mRNA level of this gene was also observed in cells treated with $50 \mu \mathrm{mol} / / \mathrm{H}_{2} \mathrm{O}_{2}$ (higher concentration of hydrogen peroxide did not exert any influence), but without statistical significance $(p>0.05)$. Pretreatment of TNF- $\alpha$-stimulated cells with NAC resulted in lower COX-2 mRNA expression by about $25 \%$, but the difference did not reach significance. The group of cells incubated with this antioxidant alone did not show any changes in the mRNA level of COX-2. The detailed results are presented in Figure 3.

\section{B}

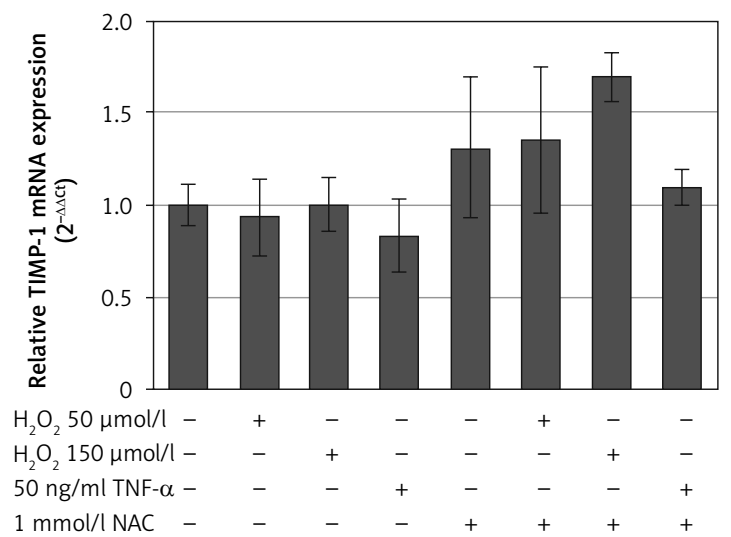

Figure 1. MMP-2 (A) and TIMP-1 (B) mRNA expression levels in HASMCs subjected to oxidative stress. HASMCs were incubated for $24 \mathrm{~h}$ with $\mathrm{H}_{2} \mathrm{O}_{2}(50 \mu \mathrm{mol} / \mathrm{l}$ or $150 \mu \mathrm{mol} / \mathrm{l}), 50 \mathrm{ng} / \mathrm{ml} \mathrm{TNF}-\alpha$ or $1 \mathrm{mmol} / \mathrm{l} \mathrm{NAC}$, either alone or in combination. Untreated cells constituted the control group. The mRNA levels were measured by real-time PCR. Histograms indicate mean \pm SD 
A

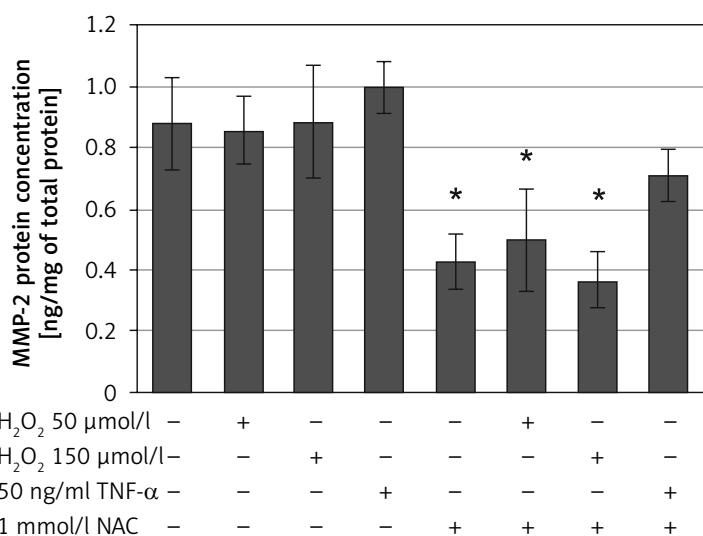

B

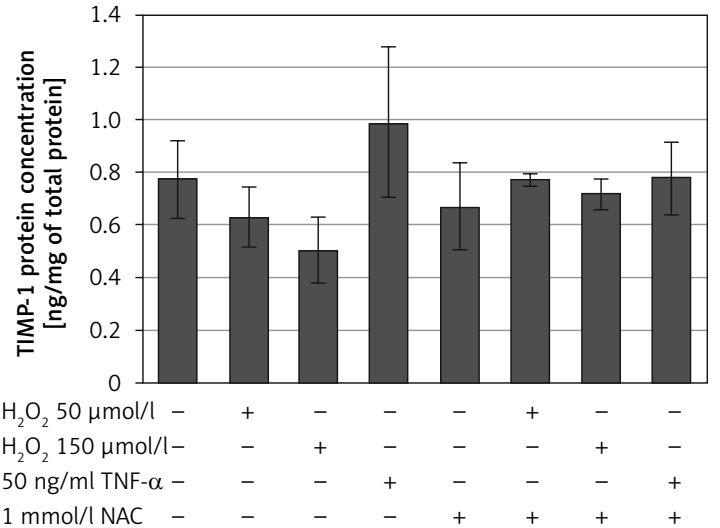

Figure 2. MMP-2 (A) and TIMP-1 (B) protein secretion into the culture supernatants from HASMCs subjected to oxidative stress. HASMCs were incubated for $24 \mathrm{~h}$ with $\mathrm{H}_{2} \mathrm{O}_{2}(50 \mu \mathrm{mol} / \mathrm{l}$ or $150 \mu \mathrm{mol} / \mathrm{l}), 50 \mathrm{ng} / \mathrm{ml} \mathrm{TNF- \alpha} \mathrm{or}$ $1 \mathrm{mmol} / / \mathrm{NAC}$, either alone or in combination. Untreated cells constituted the control group. The protein levels were measured by ELISA. Histograms indicate mean \pm SD. ${ }^{*} p<0.05$ vs. control (according to Tukey's post-hoc test after one-way ANOVA)

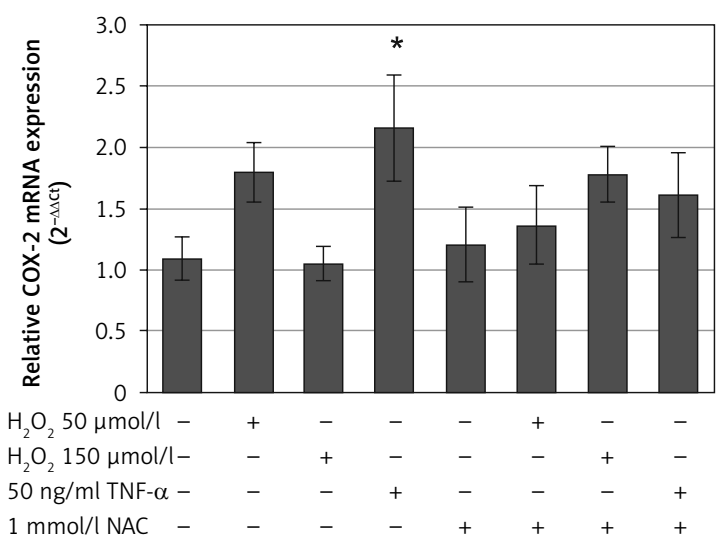

Figure 3. COX-2 mRNA expression level in HASMCs subjected to oxidative stress. HASMCs were incubated for $24 \mathrm{~h}$ with $\mathrm{H}_{2} \mathrm{O}_{2}(50 \mu \mathrm{mol} / \mathrm{l}$ or $150 \mu \mathrm{mol} / \mathrm{l})$, $50 \mathrm{ng} / \mathrm{ml}$ TNF- $\alpha$ or $1 \mathrm{mmol} / \mathrm{I} \mathrm{NAC}$, either alone or in combination. Untreated cells constituted the control group. The mRNA levels were measured by real-time PCR. Histograms indicate mean \pm SD. * $p<$ 0.05 vs. control (according to Tukey's post-hoc test after one-way ANOVA)

The activity of COX-2 enzyme was determined by measuring the level of its reaction product $P G E_{2}$, being released outside the cells. Figure 4 shows that treatment of cells with TNF- $\alpha$ increases the activity of COX-2 enzyme by nearly $40 \%$, but the difference is statistically insignificant. In contrast, $\mathrm{H}_{2} \mathrm{O}_{2}$-induced cells secreted much less PGE2 into cell culture medium than control cells (by about $60 \%$ for $150 \mu \mathrm{mol} / / \mathrm{H}_{2} \mathrm{O}_{2}, p=0.003$ ). Preincubation of $\mathrm{H}_{2} \mathrm{O}_{2}$-treated cells with NAC abolished this effect.

\section{The effect of COX-2 inhibition on expression of MMP-2 and TIMP-1}

Inhibition of cyclooxygenase 2 activity using the selective COX-2 inhibitor DuP-697 did not result in

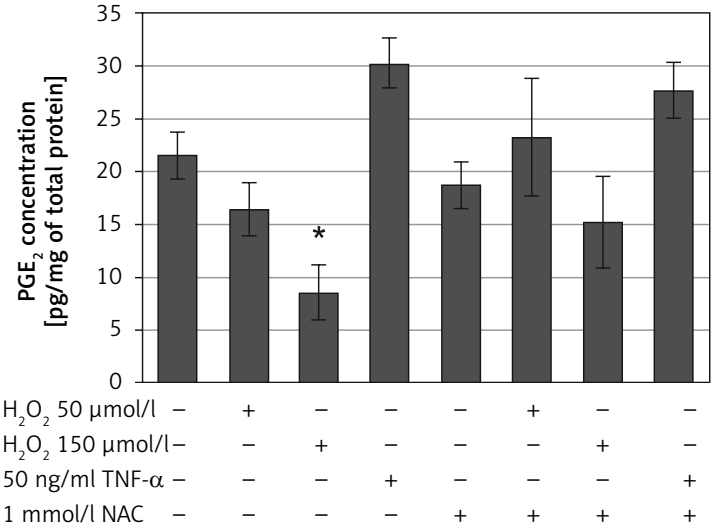

Figure 4. Concentration of prostaglandin $\mathrm{PGE}_{2}$ in the cell culture supernatants. HASMCs were incubated for $24 \mathrm{~h}$ with $\mathrm{H}_{2} \mathrm{O}_{2}(50 \mu \mathrm{mol} / /$ or $150 \mu \mathrm{mol} / \mathrm{l})$, $50 \mathrm{ng} / \mathrm{ml} \mathrm{TNF}-\alpha$ or $1 \mathrm{mmol} / \mathrm{I} \mathrm{NAC}$, either alone or in combination. Untreated cells constituted the control group. Prostaglandin levels were measured by ELISA. Histograms indicate mean $\pm \mathrm{SD} .{ }^{*} p<0.05$ vs. control (according to Tukey's post-hoc test after one-way ANOVA)

changes in MMP-2 and TIMP-1 mRNA expression or protein activity measured as the amount of PGE2 secreted outside the cells (Figure 5).

\section{Discussion}

Although the influence of oxidative stress on metalloproteinases expression and activity has been studied from many years, the results have not provided conclusive information in this area. Several published articles indicate that ROS contribute to the induction of expression and activity of various metalloproteinases [15]. Here, we investigated the effects of oxidative stress originating from different sources on the expression of MMP-2 and its inhibitor TIMP-1 in human aortic 
A

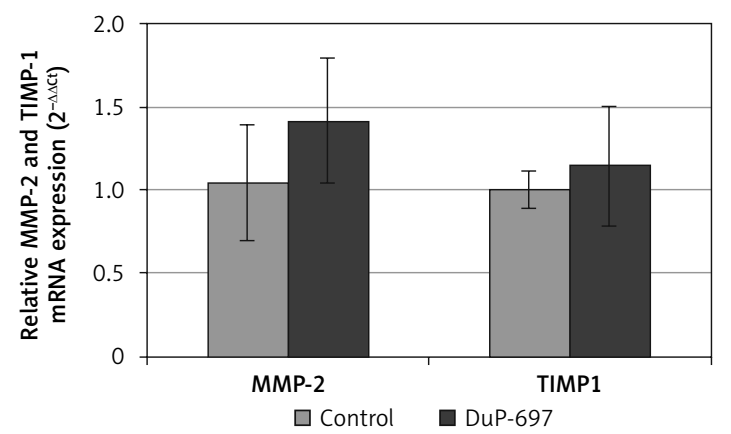

B

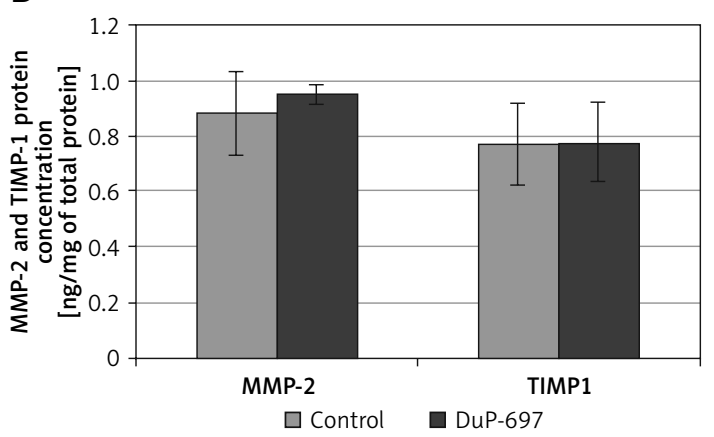

Figure 5. The effect of COX-2 inhibition by DuP-697 on expression of MMP-2 and TIMP-1 at the level of mRNA (A) and protein (B) release. HASMCs were incubated for $24 \mathrm{~h}$ with $10 \mathrm{nmol} / \mathrm{l}$ DuP-697. Cells without treatment constituted the control group. The mRNA levels were measured by real-time PCR and the protein secretion into the culture supernatant using ELISA. Histograms indicate mean \pm SD

smooth muscle cells. Vascular smooth muscle cells are the cellular components of the normal blood vessel wall that maintain structural integrity and regulate vascular tone. SMCs produce the majority of the extracellular matrix (ECM) structural constituents as well as a large number of proteolytic enzymes (such as matrix metalloproteinases) responsible for the balance between synthesis and degradation of the ECM.

In this research HASMCs were subjected to exogenously supplied hydrogen peroxide or TNF- $\alpha$ in order to assess their influence on the mRNA expression and protein secretion of MMP-2 and TIMP-1. Hydrogen peroxide is thought to be the principal redox signaling molecule in many biological processes such as cell proliferation and differentiation, tissue repair, inflammation, circadian rhythm and aging [16]. This non-radical ROS can modulate gene expression through the regulation of synthesis, stability, subcellular localization and activity of many various transcription factors [17]. $\mathrm{H}_{2} \mathrm{O}_{2}$ may also influence protein activity via reversible oxidation of its targets including protein tyrosine phosphatases, protein tyrosine kinases, receptor tyrosine kinases and transcription factors [18].

The literature data concerning the regulation of MMP-2 expression level and activity by hydrogen peroxide are ambiguous. It is determined that $\mathrm{H}_{2} \mathrm{O}_{2}$ increases MMP-2 activity in endothelial cells [19], fibroblasts [20, 21], dental pulp cells [22], cardiomyocytes [23] or vascular smooth muscle cells [24], whereas other results show the inhibitory effect of $\mathrm{H}_{2} \mathrm{O}_{2}$ on MMP-2 activity [25]. The discrepancies may depend on the hydrogen peroxide concentration used, as was previously observed [26, 27]. Zhang et al. [27] examined the effect of 0.2$0.8 \mathrm{mmol} / / \mathrm{H}_{2} \mathrm{O}_{2}$ on MMP-2 mRNA level in human uterosacral ligament fibroblasts and they found a decrease in MMP-2 mRNA at $0.2 \mathrm{mmol} / \mathrm{l}$ and an increase at $0.8 \mathrm{mmol} / \mathrm{l}$. Treatment of the cells with $0.4 \mathrm{mmol} / \mathrm{I}_{2} \mathrm{O}_{2}$ did not cause any significant effect in that experiment. In our research we did not find any relevant difference either in MMP-2 mRNA level or protein release after stimulation of the HASMCs with $\mathrm{H}_{2} \mathrm{O}_{2}$ at a concentration of 50 and $150 \mu \mathrm{mol} / \mathrm{l}$. Therefore, extended studies with a wider range of $\mathrm{H}_{2} \mathrm{O}_{2}$ concentration are still required to obtain more consistent results.

To date, there have been a few studies concerning the involvement of ROS in modulation of TIMP-1 level, but they did not give clear results. In the study conducted by Hemmerlein et al. [28] TIMP-1 mRNA levels remained unaffected in renal cell carcinoma subjected to $\mathrm{H}_{2} \mathrm{O}_{2}$. Farrokhi et al. [29] reported that $\mathrm{H}_{2} \mathrm{O}_{2}$ diminished the TIMP-1 mRNA level in vascular smooth muscle cells after $48 \mathrm{~h}$ of incubation, but did not cause any changes in TIMP-1 expression when incubation with $\mathrm{H}_{2} \mathrm{O}_{2}$ lasted for $24 \mathrm{~h}$. The results are consistent with our observation after $24 \mathrm{~h}$ of incubation of $\mathrm{HASMCS}$ with $\mathrm{H}_{2} \mathrm{O}_{2}$.

In this project HASMCs were also stimulated with $50 \mathrm{ng} / \mathrm{ml}$ TNF- $\alpha$, which is known to induce endogenous production of $\mathrm{H}_{2} \mathrm{O}_{2}$ [30-32]. The results obtained here did not show any significant differences in MMP-2 and TIMP-1 mRNA quantity or protein secretion in comparison to untreated control cells. Previous studies conducted by other authors gave divergent results. TNF- $\alpha$ increased MMP-2 expression and activity in HASMCs in the study by Zhang and Wang [33]. On the other hand, this cytokine had a negligible effect on MMP-2 secretion by myometrium SMCs [34], Fanconi anemia fibroblasts [35] and human melanoma A-2058 cells [36]. Therefore, further studies are needed to better understand these relationships.

Although we did not observe any influence of $\mathrm{H}_{2} \mathrm{O}_{2}$ or TNF- $\alpha$ on the MMP-2 and TIMP-1 expression levels, we noted significantly diminished MMP-2 protein secretion by HASMCs in all groups of cells pretreated with $1 \mathrm{mmol} / \mathrm{l} \mathrm{N}$-acetylcysteine. Simultaneously, the MMP-2 mRNA quantity remained unchanged. There are several published 
data proving that various antioxidants and sulfurous compounds may directly inhibit some metalloproteinases [37-40]. NAC contains abundant cysteine residues which can interfere with the process of the "cysteine switch" during MMP activation [41].

Additionally, in this research we examined the influence of oxidative stress on the amount of COX-2 mRNA and protein activity. We found that $\mathrm{H}_{2} \mathrm{O}_{2}$ at concentration of $150 \mu \mathrm{mol} / / \mathrm{mark}$ edly lowered the $P G E_{2}$ secretion from HASMCS, but did not affect the COX-2 mRNA level. On the other hand, in the cells subjected to TNF- $\alpha$ we observed significantly elevated mRNA and enzyme activity, which may suggest different mechanisms of action of these two compounds in HASMCs. Similarly to our results, the stimulating effect of TNF- $\alpha$ on COX-2 mRNA and activity has been observed in several other studies conducted on myofibroblasts [42, 43], human FDC-like cell line [44], follicular dendritic cells [45] or human umbilical vein endothelial cells [46]. However, our results demonstrating the influence of hydrogen peroxide on COX-2 mRNA expression and protein release from the HASMCs are not consistent with previously published data which generally report upregulation of COX-2 upon $\mathrm{H}_{2} \mathrm{O}_{2}$ treatment in cell lines [47, 48] and animal models [49-51]. This could suggest that the effect may depend on the cell types or $\mathrm{H}_{2} \mathrm{O}_{2}$ concentration.

Since the current literature demonstrates that COX-2 may be involved in the upregulation of some metalloproteinases [52-54], we attempted to determine a possible relationship between COX-2 activity and MMP-2 and TIMP-1 expression level in HASMCs. For this purpose we measured the concentration of mRNA and protein released from the cells after their pretreatment with the COX-2 selective inhibitor DuP-697. However, the obtained results show no changes in MMP-2 and TIMP-1 expression in these conditions.

Nonetheless, the findings of the research should be interpreted in light of certain limitations. One of them is not taking into account the possibility of coexistence of additional mechanisms stimulating endogenous $\mathrm{H}_{2} \mathrm{O}_{2}$ production or TNF- $\alpha$ activation. So, in further studies, the levels of $\mathrm{H}_{2} \mathrm{O}_{2}$ and TNF- $\alpha$ should be measured in cells before and after cells' treatment. The next limitation is the narrow concentration range of tested compounds and lack of analysis showing the effect depending on time of cell incubation. Such experiments could give better insight into the investigated process.

In conclusion, in this study we did not find any effect of oxidative stress, represented by $\mathrm{H}_{2} \mathrm{O}_{2}$ treatment, or its endogenous generation after exposure of HASMCS to TNF- $\alpha$ on the expression of MMP-2 and TIMP-1. However, we observed markedly reduced MMP-2 secretion in cells incubated with NAC. Moreover, HASMCs stimulated with TNF- $\alpha$ demonstrated significant increases in COX-2 mRNA level and enzyme activity. But there was no correlation between COX-2 activity and MMP-2 and TIMP-1 mRNA expression or protein secretion. We anticipate that the obtained results will provide important insights for understanding the effects of ROS on the ECM remodeling components.

\section{Acknowledgments}

This work was supported by a grant from the Polish National Science Centre (2012/05/B/ $\mathrm{NZ3/01980)}$ and by a research grant from the Medical University of Lodz (502-03/6-086-01/50264-066).

\section{Conflict of interest}

The authors declare no conflict of interest.

\section{References}

1. Murphy G, Nagase H. Progress in matrix metalloproteinase research. Mol Aspects Med 2008; 29: 290-308.

2. Zitka O, Kukacka J, Krizkova S, et al. Matrix metalloproteinases. Curr Med Chem 2010; 17: 3751-68.

3. Sundström J, Evans JC, Benjamin EJ, et al. Relations of plasma total TIMP-1 levels to cardiovascular risk factors and echocardiographic measures: the Framingham heart study. Eur Heart J 2004; 25: 1509-16.

4. Azevedo A, Prado AF, Antonio RC, Issa JP, Gerlach RF. Matrix metalloproteinases are involved in cardiovascular diseases. Basic Clin Pharmacol Toxicol 2014; 115: 301-14.

5. Lizotte-Waniewski M, Brew K, Hennekens CH. Hypothesis: metalloproteinase inhibitors decrease risks of cardiovascular disease. J Cardiovasc Pharmacol Ther 2016; 21: 368-71.

6. Spinale FG, Sapp AA. Cardiovascular risk and matrix metalloproteinase polymorphisms. Circ Cardiovasc Genet 2017; 10: e001958.

7. Xu X, Wang Y, Chen Z, Sternlicht MD, Hidalgo M, Steffensen B. Matrix metalloproteinase-2 contributes to cancer cell migration on collagen. Cancer Res 2005; 65: 130-6.

8. Gong Y, Scott E, Lu R, XU Y, Oh WK, Yu Q. TIMP-1 promotes accumulation of cancer associated fibroblasts and cancer progression. PLoS One 2013; 8: e77366.

9. Daniele A, Abbate I, Oakley C, et al. Clinical and prognostic role of matrix metalloproteinase-2, -9 and their inhibitors in breast cancer and liver diseases: a review. Int J Biochem Cell Biol 2016; 77: 91-101.

10. Song $\mathrm{G}$, Xu S, Zhang H, et al. TIMP1 is a prognostic marker for the progression and metastasis of colon cancer through FAK-PI3K/AKT and MAPK pathway. J Exp Clin Cancer Res 2016; 35: 148.

11. Şahin M, Şahin E, Gümüşlü S. Cyclooxygenase-2 in cancer and angiogenesis. Angiology 2009; 60: 242-53.

12. Muñoz M, Sánchez A, Pilar Martínez M, et al. COX-2 is involved in vascular oxidative stress and endothelial dysfunction of renal interlobar arteries from obese Zucker rats. Free Radic Biol Med 2015; 84: 77-90.

13. Livak KJ, Schmittgen TD. Analysis of relative gene expression data using real-time quantitative PCR and the 
2(-Delta Delta C(T)) method. Methods San Diego Calif 2001; 25: 402-8

14. Schmittgen TD, Livak KJ. Analyzing real-time PCR data by the comparative $C(T)$ method. Nat Protoc 2008; 3 : 1101-8.

15. Nelson KK, Melendez JA. Mitochondrial redox control of matrix metalloproteinases. Free Radic Biol Med 2004; 37: 768-84.

16. Lismont C, Revenco I, Fransen M. Peroxisomal hydrogen peroxide metabolism and signaling in health and disease. Int J Mol Sci 2019; 20: 3673.

17. Marinho HS, Real C, Cyrne L, Soares H, Antunes F. Hydrogen peroxide sensing, signaling and regulation of transcription factors. Redox Biol 2014; 2: 535-62.

18. Rhee SG, Bae YS, Lee SR, Kwon J. Hydrogen peroxide: a key messenger that modulates protein phosphorylation through cysteine oxidation. Sci Signal 2000; 2000: pe1.

19. Belkhiri A, Richards C, Whaley M, McQueen SRA, Orr FW. Increased expression of activated matrix metalloproteinase- 2 by human endothelial cells after sublethal $\mathrm{H}_{2} \mathrm{O}_{2}$ exposure. Lab Investig J Tech Methods Pathol 1997; 75: 533-9.

20. Siwik DA, Pagano PJ, Colucci WS. Oxidative stress regulates collagen synthesis and matrix metalloproteinase activity in cardiac fibroblasts. Am J Physiol Cell Physiol 2001; 280: C53-60.

21. Osorio C, Cavalla F, Paula-Lima A, et al. H2O2 activates matrix metalloproteinases through the nuclear factor kappa B pathway and Ca2+ signals in human periodontal fibroblasts. J Periodontal Res 2015; 50: 798-806.

22. Kim DS, Kang SI, Lee SY, Noh KT, Kim EC. Involvement of SDF-1 and monocyte chemoattractant protein-1 in hydrogen peroxide-induced extracellular matrix degradation in human dental pulp cells. Int Endod J 2014; 47: 298-308.

23. Ali MAM, Kandasamy AD, Fan X, Schulz R. Hydrogen peroxide-induced necrotic cell death in cardiomyocytes is independent of matrix metalloproteinase-2. Toxicol In Vitro 2013; 27: 1686-92.

24. Hu T, Luan R, Zhang H, et al. Hydrogen peroxide enhances osteopontin expression and matrix metalloproteinase activity in aortic vascular smooth muscle cells. Clin Exp Pharmacol Physiol 2009; 36: 626-30.

25. Ganguly K, Kundu P, Banerjee A, Reiter RJ, Swarnakar S. Hydrogen peroxide-mediated downregulation of matrix metalloprotease- 2 in indomethacin-induced acute gastric ulceration is blocked by melatonin and other antioxidants. Free Radic Biol Med 2006; 41: 911-25.

26. Rajagopalan S, Meng XP, Ramasamy S, Harrison DG, Galis ZS. Reactive oxygen species produced by macrophage-derived foam cells regulate the activity of vascular matrix metalloproteinases in vitro. Implications for atherosclerotic plaque stability. J Clin Invest 1996; 98: 2572-9.

27. Zhang Q, Liu C, Hong S, et al. Excess mechanical stress and hydrogen peroxide remodel extracellular matrix of cultured human uterosacral ligament fibroblasts by disturbing the balance of MMPs/TIMPs via the regulation of TGF- $\beta 1$ signaling pathway. Mol Med Rep 2017; 15 : 423-30.

28. Hemmerlein B, Johanns U, Halbfass J, et al. The balance between MMP-2/-9 and TIMP-1/-2 is shifted towards MMP in renal cell carcinomas and can be further disturbed by hydrogen peroxide. Int J Oncol 2004; 24: 1069-76.

29. Farrokhi E, Ghatreh-Samani K, Salehi-Vanani N, Mahmoodi $A$. The effect of resveratrol on expression of matrix metalloproteinase 9 and its tissue inhibitors in vascular smooth muscle cells. ARYA Atheroscler 2018; 14: $157-62$.

30. Deshpande SS, Angkeow P, Huang J, Ozaki M, Irani K. Rac1 inhibits TNF- $\alpha$-induced endothelial cell apoptosis: dual regulation by reactive oxygen species. FASEB J 2000; 14: 1705-14.

31. Young CN, Koepke J, Terlecky LJ, Borkin MS, Boyd SL, Terlecky SR. Reactive oxygen species in tumor necrosis factor- $\alpha$-activated primary human keratinocytes: implications for psoriasis and inflammatory skin disease. J Invest Dermatol 2008; 128: 2606-14.

32. Han BH, Yoon JJ, Kim HY, et al. Inhibitory effects of herbal decoction Ojeoksan on proliferation and migration in vascular smooth muscle cells. J Physiol Pharmacol 2019; 70: 287-94.

33. Zhang HS, Wang SQ. Salvianolic acid B from Salvia miltiorrhiza inhibits tumor necrosis factor-alpha (TNF-alpha)-induced MMP-2 upregulation in human aortic smooth muscle cells via suppression of $\mathrm{NAD}(\mathrm{P}) \mathrm{H}$ oxidase-derived reactive oxygen species. J Mol Cell Cardiol 2006; 41: 138-48.

34. Wang Y, Feng G, Wang J, et al. Differential effects of tumor necrosis factor- $\alpha$ on matrix metalloproteinase- 2 expression in human myometrial and uterine leiomyoma smooth muscle cells. Hum Reprod 2015; 30: 61-70.

35. Roomi MW, Kalinovsky T, Rath M, Niedzwiecki A. Cytokines, inducers and inhibitors modulate MMP-2 and MMP-9 secretion by human Fanconi anemia immortalized fibroblasts. Oncol Rep 2017; 37: 1842-8.

36. Roomi MW, Kalinovsky T, Niedzwiecki A, Rath M. Modulation of MMP-2 and -9 secretion by cytokines, inducers and inhibitors in human melanoma A-2058 cells. Oncol Rep 2017; 37: 3681-7.

37. Albini A, D’Agostini F, Giunciuglio D, Paglieri I, Balansky R, Flora SD. Inhibition of invasion, gelatinase activity, tumor take and metastasis of malignant cells by $\mathrm{N}$-acetylcysteine. Int J Cancer 1995; 61: 121-9.

38. Weiss A, Goldman S, Shlomo IB, Eyali V, Leibovitz S, Shalev E. Mechanisms of matrix metalloproteinase- 9 and matrix metalloproteinase- 2 inhibition by $\mathrm{N}$-acetylcysteine in the human term decidua and fetal membranes. Am J Obstet Gynecol 2003; 189: 1758-63.

39. Voronkina IV, Vakhromova EA, Kirpichnikova KM, Smagina LV, Gamaley IA. Matrix metalloproteinase activity in transformed cells exposed to an antioxidant. Cell Tissue Biol 2015; 9: 16-23.

40. Li J, Xu L, Deng X, et al. N-acetyl-cysteine attenuates neuropathic pain by suppressing matrix metalloproteinases. Pain 2016; 157: 1711-23.

41. Van Wart HE, Birkedal-Hansen $H$. The cysteine switch: a principle of regulation of metalloproteinase activity with potential applicability to the entire matrix metalloproteinase gene family. Proc Natl Acad Sci USA 1990; 87: 5578-82.

42. Yoo J, Rodriguez Perez CE, Nie W, Sinnett-Smith J, Rozengurt E. TNF- $\alpha$ and LPA promote synergistic expression of COX-2 in human colonic myofibroblasts: role of LPA-mediated transactivation of upregulated EGFR. BMC Gastroenterol 2013; 13: 90.

43. Saini S, Liu T, Yoo J. TNF- $\alpha$ stimulates colonic myofibroblast migration via COX-2 and Hsp27. J Surg Res 2016; 204: 145-52.

44. Lee IY, Cho W, Kim J, Park CS, Choe J. Human follicular dendritic cells interact with $T$ cells via expression and regulation of cyclooxygenases and prostaglandin $\mathrm{E}$ and I synthases. J Immunol 2008; 180: 1390-7. 
45. Kim J, Lee S, Jeoung D, Kim YM, Choe J. Activated human $B$ cells stimulate COX-2 expression in follicular dendritic cell-like cells via TNF- $\alpha$. Mol Immunol 2018; 94: 1-6.

46. Eligini S, Stellabarbieri S, Cavalca V, et al. Diversity and similarity in signaling events leading to rapid Cox-2 induction by tumor necrosis factor-alpha and phorbol ester in human endothelial cells. Cardiovasc Res 2005; 65: 683-93.

47. Eligini S, Arenaz I, Barbieri S. Cyclooxygenase-2 mediates hydrogen peroxide-induced wound repair in human endothelial cells. Free Radic Biol Med 2009; 46: 1428-36.

48. Onodera Y, Teramura T, Takehara T, Shigi K, Fukuda K. Reactive oxygen species induce Cox-2 expression via TAK1 activation in synovial fibroblast cells. FEBS Open Bio 2015; 5: 492-501.

49. Tian XY, Wong WT, Leung FP, et al. Oxidative stress-dependent cyclooxygenase-2-derived prostaglandin $\mathrm{F} 2 \alpha$ impairs endothelial function in renovascular hypertensive rats. Antioxid Redox Signal 2012; 16: 363-73.

50. Santiago E, Martínez MP, Climent B, et al. Augmented oxidative stress and preserved vasoconstriction induced by hydrogen peroxide in coronary arteries in obesity: role of COX-2. Br J Pharmacol 2016; 173: 3176-95.

51. Silva BR, Pernomian L, De Paula TD, Grando MD, Bendhack LM. Endothelial nitric oxide synthase and cyclooxygenase are activated by hydrogen peroxide in renal hypertensive rat aorta. Eur J Pharmacol 2017; 814: 87-94.

52. Mrena J, Wiksten JP, Nordling S, Kokkola A, Ristimäki A, Haglund C. MMP-2 but not MMP-9 associated with COX-2 and survival in gastric cancer. J Clin Pathol 2006; 59: 618-23.

53. Bu X, Zhao C, Dai X. Involvement of COX-2/PGE2 pathway in the upregulation of MMP-9 expression in pancreatic cancer. Gastroenterol Res Pract 2011; 2011: 214269.

54. Mohammad MA, Zeeneldin AA, Abd Elmageed ZY, et al. Clinical relevance of cyclooxygenase- 2 and matrix metalloproteinases (MMP-2 and MT1-MMP) in human breast cancer tissue. Mol Cell Biochem 2012; 366: 269-75. 